\title{
DEADLINE SETTLEMENT OF PETITION FOR DECLARATION OF BANKRUPTCY BEFORE THE COMMERCIAL COURT AND THE LEGAL CONSEQUENCES ACCORDING TO LAW NUMBER 37 OF 2004 ON BANKRUPTCY AND SUSPENSION OF DEBT PAYMENT OBLIGATIONS
}

\author{
Tata Wijayanta \\ Faculty Of Law Universitas Gadjah Mada, Yogyakarta, Indonesia \\ Email: wijayanta@mail.ugm.ac.id
}

\begin{abstract}
This study aimed to identify and analyze (1) the regulation regarding the deadline for applications of bankruptcy, (2) the practice of the deadline regulation, and (3) the legal consequences when they do not heed the deadline. This research is a normative legal research supported by interviews with informants. The data were collected through documentation method with document study tool, while the data from the informants were collected through interviews by using interview manual tool. The secondary data were analyzed by content analysis with statute approach, while the analysis of the interview data was conducted through a qualitative analysis. The results and discussion show that the Bankruptcy and PKPU Act applies because the previous bankruptcy regulation was not effective because it did not regulate the deadline for settling bankruptcy, so that it's a long period of time. The regulation of deadline for bankruptcy settlement in 2015 was largely complied with the provisions of law. $87 \%$ of the verdicts (14 out of 16 verdicts) were made within less than 60 days, while $13 \%$ (2 verdicts) were made beyond the time period specified by law. The Bankruptcy and PKPU Act does not regulate any legal sanctions/effects in relation to the deadline for judges who handle bankruptcy petitions, however, the common sanctioning relates to the assessment of the judges' performance.
\end{abstract}

Keywords: deadline, bankruptcy, settlement of petition, Bankruptcy and PKPU Act

\section{A. INTRODUCTION}

In resolving disputes in court, the justice seekers generally prefer to use the quick dispute settlement method, even though the decisions are less satisfactory than objective judgments which take years to decide. Justice seekers expect immediate certainty about the case that might determine their lives and not be overturned due to the protracted resolution of the case which resulted in the uncertainty. With regard to the period of the settlement, it is not surprising that the issue of justice delayed is justice denied was arised. (Sudikno Mertokusumo, 1998: 34)

Yustisia Vol. 7 Number 3 (Sept.-Dec. 2018)

Deadline Settlement Of Petition ...

(C)2018; This is an Open Acces Research distributed under the term of the Creative Commons Attribution Licencee (https://Creativecommons.org/licences/by/4.0), which permits unrestricted use, distribution, and reproduction in any medium, provided the original works is properly cited. 
In resolving disputes in court, there are common principles such as the simple, fast and low-cost principle. The word "quick" refers to the course of the trial. Examination of cases in court with many formalities is an obstacle to the trial. The obstacles are not only in the course of the trial when examine the case before the court, but also the physical inspection report completion before the court until the signatory of the verdict by the judge and the implementation of the decision.

The inspection of the case are often delayed. The various causes which have resulted in delays of dispute settlement in the court are the witness that did not come, or the parties alternately not coming to the trial even though they had been properly summoned, or the parties asked the court to postpone the trial schedule has been set by the judges. Moreover, the phenomenon of the case was continued by the heirs has become common in civil cases in court proceeding. The inspection of the case before the court which takes long period of time resulted in the derivation of court authority and decreases public trust in a court as an authorized institution to settle dispute.

According to this fact, the Supreme Court of the Republic of Indonesia issued Circular Letter of the Supreme Court of the Republic of Indonesia Number 2 of 2014 on Dispute Settlement at the District Court and the Appeals Court in 4 Judicator.

Circular Letter of the Supreme Court of the Republic of Indonesia (SEMA RI) Number 2 of 2014 on Dispute Settlement at the District Court and the Appeals Court in 4 Judicator.revoked the previous enactment of the Circular Letter of the Supreme Court of the Republic of Indonesia (SEMA RI) Number 9 of 1992 on Dispute Settlement at the District Court and the Appeals Court and Circular Letter of the Supreme Court of the Republic of Indonesia Number 3 of 1998 on the maximum period of Dispute Settlement for 6 Months. The differences of SEMA RI Number 2 of 2014 with the previous SEMA is the current regulation shortened the period of the civil cases to five months which previously stipulated in the previous SEMA appealed by the Supreme Court to be resolved for a maximum period of six months.

The SEMA RI Number 2 of 2014 on Dispute Settlement at the District Court and the Appeals Court in 4 Judicator excludes cases that are examined and decided by special courts. Further, the regulation stated that the provisions of deadline application do not apply to special cases determined by the legislation.

The petition for declaration of bankruptcy requested for examination and verdict to the commercial court is one of the particular case. In contrast to the settlement of civil cases in the district court, in examining cases of petition for declaration of bankruptcy in the commercial court, Law Number 37 of 2004 on Bankruptcy and Suspension of Debt Payment Obligation (hereinafter referred to UUK PKPU) regulates the deadline for examining act of bankruptcy in the commercial court.

520 Yustisia Vol. 7 Number 3 (Sept.-Dec. 2018) $\quad$ Deadline Settlement Of Petition ... 
Article 8 paragraph (5) of the $U U K$ PKPU states that a Court Decision on petition for declaration of bankruptcy must be resolved no later than 60 days after the date of registration.

\section{B. PROBLEM STATEMENT}

Based on these overview, the problems examined in this study are 1) why does the Law Number 37 of 2004 on Bankruptcy and Suspension of Debt Payment Obligation (UUK PKPU) regulate the provisions on the deadline for resolving petition for declaration of bankruptcy in commercial courts? 2) How does the deadline regulation implemented by the judge in examining and deciding the petition for declaration of bankruptcy at the commercial court? and what are the legal consequences for judges who examine petition for declaration of bankruptcy if they do not heed the deadline regulation for examining petition for declaration of bankruptcy?

\section{RESEARCH METHODS}

research is a normative legal research that is supported/supplemented by interviewing the judges of commercial court and the bankruptcy attorney. The datas in this study are secondary data sourced from primary, secondary and tertiary legal materials, while interview is complementary.

The method of secondary data collection has conducted by documentation which refers to documented library materials contained in primary legal materials, secondary legal materials and teriser legal materials (Ranjit Kumar, 1999: 104), while the tools are study document. The Study documents such as study by learning data from books, research reports, seminar papers, writings of experts, court decisions and all regulations relating to research material. While interviews with informants is being the supported/supplemented data of the normative research is a method of collecting research data, while the data collection method is based on the interview guides.

The analysis of the first problem formulation is why UUK PKPU provide a regulation of deadline for settlement of petition for declaration of bankruptcy in commercial courts conducted by content analysis with a statute approach. Analysis of the data on the second and third problem formulations is how the deadline regulation is implemented by the judge in examining and deciding petition for declaration of bankruptcy in the commercial court and how the legal consequences for judges examining petition for declaration of bankruptcy if they do not heed the deadline for examining petition for declaration of bankruptcy using qualitative analysis. 


\section{DISCUSSION AND RESEARCH RESULTS}

\section{1. $U U K P K P U$ provides for the regulation of the deadline for resolving petition for declaration of bankruptcy at the commercial court.}

UUK PKPU revoked the enactment of Law Number 4 of 1998 on Government Regulation in Lieu of Law Number 1 of 1998 on Bankruptcy Law is intended because enactment of the previous bankruptcy legislation namely Verordening op de Faillissement en Surceance van Betaling (Faillisement verordening $(F v)$ ) or Bankruptcy Regulations and Suspension of Debt Payment Obligation (Bankruptcy Regulations (PK)) [Staatblad ( Stb.) 1905-217 jo Stb.1906-348] which regulated bankruptcy was considered ineffective in regulating and resolving bankruptcy cases after the economic crisis hit Indonesia.

Bankruptcy and its regulation became a leading issue when Indonesia and all major Asian countries were in the economic crisis (Bhagwam Chowdhry and Amit Goyal: 135). The economic crisis that began to occur in mid-1997 and has resulted in an uncertain stock market and economic instability in most Asian countries. This situation conduced in the increase bankruptcy and insisted the International Monetary Fund (IMF) to take action in order to save countries from the crisis (Giancarlo Corsetti, Paolo Pesenti and Nauriel Roubini, 1999: 305-306).

The economic crisis also led to an increase number of companies and individuals who were unable to pay debts. Hundreds of banks (S. Radelet and J. Sachs: 714) and thousands of debtors were taken over by the government through the National Bank Restructuring Agency (BPPN). A total of 398 companies, including the State-Owned Enterprises $(B U M N)$ that were inefficient and always protected by the government fell bankrupt (Todd Mitton, 2002: 215) and this resulted in an increase in unemployment which at that time reached 40 million people ( C. Manning, 2000: 32).

At the beginning of the 1997 economic crisis, the Indonesian government signed and ratified 18 Letter of Intent (LoI) with the International Financial Fund (IMF). The 17 LoIs stressed the demand for a mechanism to rise after the economic crisis through the settlement of bankruptcy cases in commercial courts (CH. Himawan, 1998: 6).

The dispute settlement is based on Verordening op de Faillissement en Surceance van Betaling (Faillisement verordening $(F v)$ ) or Bankruptcy Regulations and Suspension of Debt Payment Obligation (Bankruptcy Regulations (PK)) [Staatblad (Stb.) 1905-217 jo Stb.1906-348] which was the regulation products of Dutch requires a long period of time in resolving the case. Bankruptcy cases at the time of enactment of the Verordening op de Faillissement en Surceance van Betaling (Faillisement verordening $(F v)$ ) or Bankruptcy Regulations

522 Yustisia Vol. 7 Number 3 (Sept.-Dec. 2018) $\quad$ Deadline Settlement Of Petition ... 
and Suspension of Debt Payment Obligation (Bankruptcy Regulations (PK)) [Staatblad (Stb.) 1905-217 jo Stb.1906-348 ] is the authority of the District Court to examine,adjudicate and decide on the bankruptcy case. Based on the provisions stipulated in the Law Number 2 of 1986 on General Courts jo with the Law Number 8 of 2004 on Amendments to the Law Number 2 of 1986 on General Courts there was no deadline regulation for settlement of cases in the District Court at that time the court also had the authority to examine, adjudicate and decide bankruptcy cases based on Verordening op de Faillissement en Surceance van Betaling (Faillisement verordening (Fv)) or Bankruptcy Regulations and Suspension of Debt Payment Obligation (Bankruptcy Regulations (PK)) [Staatblad (Stb.) 1905-217 jo Stb.1906 - 348]. The absence of provisions on the deadline for settlement of cases in the District Court also resulted in the bankruptcy case examination also lasting in the long period.

At the time before the 1997 economic crisis occurred in Indonesia, based on the valid bankruptcy law at that time (Siti Sumarti Hartono, 1982: 40; Siti Sumarti Hartono, 1980; Sutan Remy Sjahdeni, 2002: ix) until 1970, there were still many bankruptcy cases examined in courts throughout Indonesia, however, starting in 1980 no bankruptcy cases were examined in court anymore. The absence of bankruptcy registered and examined cases in the court was due to the lack of public trust (including foreign investors) to the legal system in Indonesia. The results of a 1996 study conducted by the National Development Planning Agency (Bappenas) showed the amount of corruption and lack of competence (incompetency) among judges of the court who examined and decided on commercial matters (Simon Johson, Peter Boone, Alasdair Breach, Eric Friedman, 2000: 171). This drawback was also supported by the fact that court was not giving fair giving fair decision (T. Budiyono, 2002: 4). The district court that examined the bankruptcy case at that time was not effective in resolving bankruptcy cases when the economic crisis hit Indonesia. Therefore, under the suggestion and pressure of the International Financial Fund (Giancarlo Corsetti, Paolo Pesenti and Nauriel Roubini, 1999: 309) a commercial court was formed.

Based on the ineffectiveness of the Verordening op de Faillissement en Surceance van Betaling (Faillisement verordening (Fv)) or Bankruptcy Regulations and Suspension of Debt Payment Obligation (Bankruptcy Regulations (PK)) [Staatblad (Stb.) 1905-217 jo Stb.1906 - 348] which regulates the competence of examining, adjudicating and deciding bankruptcy cases was the authority of the district court and the absence of deadline regulation for settlement of bankruptcy cases in a district court regulated under the Surceance van Betaling (Faillisement verordening $(F v)$ ) or Bankruptcy Regulations and Suspension of Debt Payment Obligation (Bankruptcy Regulations (PK)) 
[Staatblad (Stb.) 1905-217 jo Stb.1906 - 348] and Law Number 2 of 1986 on General Courts in conjunction with Law Number 8 Year 2004 on Amendment to Law Number 2 of 1986 regarding General Courts and was encouraged by the 1997 economic crisis which resulted in an increase number of bankruptcy cases, bankruptcy regulation were replaced with the Law Number 4 of 1998 on Government Regulation in Lieu of Law Number 1 of 1998 on Bankruptcy into Law (Bankruptcy Law) and further this regulation is revoked by Law Number 37 of 2004 on Bankruptcy and Suspension of Debt Payment Obligation (Bankruptcy and PKPU Law)

According to article 8 paragraph (4) of $U U K$ PKPU, Bankruptcy procedures start from the the application registration until the court decision has to be completed within no more than 60 days.

Parties who are dissatisfied and aggrieved by the decision of the closed commercial court to file an appeal to the appeal court but parties who are dissatisfied and feel aggrieved by the decision of the commercial court can submit a legal appeal directly to the Supreme Court by cassation (Jameslin Purba, 2017, Interview). If not satisfied with the decision of the cassation, then it can continue to submit a request for a review to the Supreme Court. The deadline for completing legal proceedings for a cassation request is 60 days, while the review is 30 days. The possibility of legal proceedings of bankruptcy decisions directly to the Supreme Court without proceeding in appeal court resulted in the settlement of bankruptcy cases as stipulated in UUK PKPU could be accelerated. The period of the proceeding of the case from the registration application to the commercial court until the Supreme Court's decision may only takes 150 days (Jameslin Purba, 2017, Interview).

The debt settlement must be completed quickly and effectively in court so that it can restore the trust of foreign investors and restore the country's economy at that time (Jameslin Purba, 2017, Interview), besides that the settlement of bankruptcy cases which was being completed quickly and effectively in court intended to fulfill the general principle of law such as fast, simple and low-cost principle. (Agus Subroto, 2017, Interview).

The quick dispute settlement is also conducted by carrying out the inquisitorial system for bankruptcy cases in the commercial court. The diffcult and simple burden of proof of debt cases shall resulted in long time period of settlemet which is not the authority of the commercial court.

The authority over cases where the burden of proof is complicated exercises under the authority of the district court. In the decision of the petition to review the case of PT. WRS Indonesia against Rodney Alexander Bothwell [Decree of the Supreme Court of the Republic of Indonesia Number 02 PK/N/2001]. The

524 Yustisia Vol. 7 Number 3 (Sept.-Dec. 2018) $\quad$ Deadline Settlement Of Petition ... 
Supreme Court of the Republic of Indonesia ruled that the dispute that occurred in this case was regarding the event of default between the respondent (PT WRS Indonesia) as the employer and the applicant (Rodney Alexander Bothwell) as a worker. According to the Supreme Court of Indonesia, this matter should be examined and decided prior according to the civil system in the district court, because the agreement was conducted based on a cooperation agreement which the verification process was not simple and not easy. Rodney Alexander Bothwell should register the case with the district court prior and should not the commercial court (PT Kadi Internasional v. PT Wisma Calindra [Supreme Court Decision Number 04.PK/N/2001] and PT Bank Mayapada International Tbk v. PT. Mandira Pelita Main [Decree of the Supreme Court of the Republic of Indonesia Number 33.PK/N/2001]).

Regulations concerning the deadline for settling bankruptcy cases at commercial courts within 60 days can cause settlement of cases to be faster, in accordance with the regulation of the length period and decreasing the number of bankruptcy arrears

\section{The implementation of deadline regulation by the judge in examining and} deciding bankruptcy applications at the commercial court.

The judge in examining, adjudicating and deciding the case in court shall be independent. The principle of the judge's independence means that in examining, adjudicating and deciding the case, the judge is free from interference from other parties. However, the freedom of judges is only related to the substance or subject matter of the case.

The independence of the judge does not apply in relation to the procedure of proceedings at the court. The procedure of proceedings is the stages that the judge must follow in examining, adjudicating and deciding the case. The period of dispute settlement is included in the procedure of proceedings at the court. The UUK PKPU provides a deadline for resolving bankruptcy applications in court, based on the provisions of Article 8 paragraph (5), the decision on a petition for declaration of bankruptcy must be rendered at the latest within the time period of 60 (sixty) days counted from the date the petition for declaration of bankruptcy is registered. Article 13 paragraph (3) of UUK PKPU also provides that the decision regarding the petition for cassation to the Supreme Court must be determined within 60 (sixty) days of the date such petition for cassation to the Supreme Court is registered. Great. Further, article 14 paragraph (1) also provides that civil review may be filed to the Supreme Court in from a decision concerning a petition for declaration of bankruptcy which already becomes final and binding. Completion of the Judicial Review by the Supreme Court may be no longer than 30 days. 
A commercial court is formed within the district court which later categorized as the special court. Based on this fact, in order to regulate the deadline for resolving a petition for declaration of bankruptcy in the commercial court, the applicable provisions are the provisions stipulated in the UUK PKPU, besides the commercial court is a established within the district court, however the resolvement of dispute in the district court also does not provide the deadline regulation. (Agus Subroto, 2017. Interview).

Based on secondary data in 2015, data was found that in petition for declaration of bankruptcy at the commercial court in the Medan Commercial Court, Central Jakarta Commercial Court, Semarang Commercial Court and Surabaya Commercial Court has reached the number of $87 \%$ from 14 out of 16 bankrupt decisions were completed in less than 60 days, while $13 \%$ (two decisions) completed more than the period specified by law (see tables 1, 2, 3 and 4 below).

Table1.

Duration of Petition For Declaration of Bankruptcy Settlement Medan Commercial Court (2015)

\begin{tabular}{|c|l|l|l|c|}
\hline No. & \multicolumn{1}{|c|}{ Decision Number } & $\begin{array}{l}\text { Registered } \\
\text { Date }\end{array}$ & Decided Date & Period \\
\hline 1. & $\begin{array}{l}\text { 08/Pdt . Sus - Pailit/2015/ } \\
\text { PN.Niaga. Mdn }\end{array}$ & 23 July 2015 & $\begin{array}{l}10 \text { September } \\
2015\end{array}$ & 47 hari \\
\hline 2. & $\begin{array}{l}\text { 07/Pdt.Sus-Pailit/2015/PN. } \\
\text { Niaga. Mdn }\end{array}$ & 08 July 2015 & $\begin{array}{l}03 \text { September } \\
2015\end{array}$ & 55 hari \\
\hline 3. & $\begin{array}{l}\text { 05/Pdt.Sus-Pailit/2015/PN. } \\
\text { Niaga. Mdn }\end{array}$ & 26 June 2015 & $\begin{array}{l}19 \quad \text { August } \\
2015\end{array}$ & 53 hari \\
\hline
\end{tabular}

Sumber: Data Sekunder, 2017

Table 2.

Duration of Petition For Declaration of Bankruptcy Settlement

Central Jakarta Commercial Cour (2015)

\begin{tabular}{|c|c|c|c|c|}
\hline No. & Decision Number & $\begin{array}{l}\text { Registered } \\
\text { Date }\end{array}$ & $\begin{array}{c}\text { Decided } \\
\text { Date }\end{array}$ & Period \\
\hline 1 & $\begin{array}{l}30 / \text { P d t.S u s - P a il it / } 2015 / \\
\text { PN.Niaga. Jkt.Pst }\end{array}$ & $\begin{array}{l}8 \\
\text { September } \\
2015\end{array}$ & $\begin{array}{l}1 \\
\text { N o v e m b e r } \\
2015\end{array}$ & 50 hari \\
\hline 2. & $\begin{array}{l}26 \text { / P d t. S u s - P a i l it / } 2015 / \\
\text { PN.Niaga. Jkt.Pst }\end{array}$ & $\begin{array}{l}1 \\
\text { September } \\
2015\end{array}$ & $\begin{array}{ll}23 & \text { October } \\
2015 & \end{array}$ & 43 hari \\
\hline
\end{tabular}

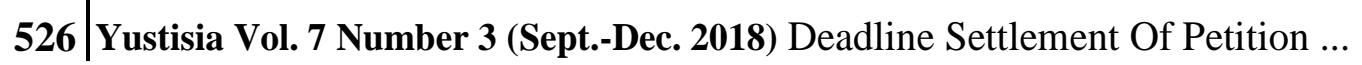




\begin{tabular}{|c|c|c|c|c|}
\hline No. & Decision Number & $\begin{array}{c}\text { Registered } \\
\text { Date }\end{array}$ & $\begin{array}{c}\text { Decided } \\
\text { Date }\end{array}$ & Period \\
\hline 3. & $\begin{array}{l}\text { 25 / P d t. S u s - P a i l it / } 2015 \text { / } \\
\text { PN.Niaga. Jkt.Pst }\end{array}$ & $\begin{array}{lr}27 & \text { August } \\
2015 & \end{array}$ & $\begin{array}{|ll|}21 & \text { October } \\
2015 & \end{array}$ & 54 hari \\
\hline 4. & $\begin{array}{l}15 / \mathrm{Pdt} . \mathrm{S} \text { u s - P a il it / } 2015 / \\
\text { PN.Niaga. Jkt.Pst }\end{array}$ & $\begin{array}{ll}09 & \text { June } \\
2015 & \\
\end{array}$ & 5 August & 56 hari \\
\hline 5. & $\begin{array}{l}0 \text { 9/P d t.S u s - P a i l it / } 2015 \text { / } \\
\text { PN.Niaga. Jkt.Pst }\end{array}$ & $\begin{array}{ll}30 & \text { April } \\
2015 & \\
\end{array}$ & 29 June 2015 & 59 hari \\
\hline 6. & $\begin{array}{l}0 \text { } 4 \text { / P d t . S u s - P a i } 1 \text { i t / } 2015 \text { / } \\
\text { PN.Niaga. Jkt.Pst jo 27/Pdt.Sus. } \\
\text { PKPU/2015/PN.-Niaga Jkt.Pst }\end{array}$ & $\begin{array}{l}1 \\
\text { F e b r u a r y } \\
2015\end{array}$ & $\begin{array}{l}16 \\
2015\end{array}$ & 58 hari \\
\hline
\end{tabular}

Sumber: Data Sekunder, 2017

Table 3.

Duration of Petition For Declaration of Bankruptcy Settlement Semarang Commercial Cour (2015)

\begin{tabular}{|l|l|l|l|l|}
\hline No. & \multicolumn{1}{|c|}{ Decision Number } & \multicolumn{1}{|c|}{$\begin{array}{l}\text { Registered } \\
\text { Date }\end{array}$} & Decided Date & Period \\
\hline 1 & $\begin{array}{l}\text { 03/Pdt . Sus - Pailit/2015/ } \\
\text { PN.Niaga. Smg. }\end{array}$ & $\begin{array}{l}12 \text { January } \\
2015\end{array}$ & $\begin{array}{l}9 \text { February } \\
2015\end{array}$ & 27 hari \\
\hline
\end{tabular}

Sumber: Data Sekunder, 2017

Table 4.

Duration of Petition For Declaration of Bankruptcy Settlement Surabaya Commercial Cour (2015)

\begin{tabular}{|c|c|c|c|c|}
\hline No. & Decision Number & $\begin{array}{l}\text { Registered } \\
\text { Date }\end{array}$ & $\begin{array}{l}\text { Decided } \\
\text { Date }\end{array}$ & Period \\
\hline 1 & $\begin{array}{l}\text { 10/Pdt . Sus - Pailit/2015/ } \\
\text { PN.Niaga. Sby }\end{array}$ & 30 July 2015 & $\begin{array}{|ll|}5 & \text { October } \\
2015 & \end{array}$ & 97 days \\
\hline 2. & $\begin{array}{l}\text { 18/Pdt . Sus - Pailit/2015/ } \\
\text { PN.Niaga. Sby }\end{array}$ & $\begin{array}{|ll|}28 & \text { October } \\
2015 & \\
\end{array}$ & $\begin{array}{l}08 \text { Desember } \\
2015\end{array}$ & 41 days \\
\hline 3. & $\begin{array}{ll}\text { 17/Pdt.Sus- } & \text { Pailit/2015/ } \\
\text { PN.Niaga. Sby } & \\
\end{array}$ & $\begin{array}{|ll|}15 & \text { October } \\
2015 & \\
\end{array}$ & $\begin{array}{l}26 \text { November } \\
2015\end{array}$ & 41days \\
\hline 4. & $\begin{array}{l}\text { 14/Pdt . Sus - Pailit/2015/ } \\
\text { PN.Niaga. Sby }\end{array}$ & $\begin{array}{|ll|}31 & \text { August } \\
2015 & \\
\end{array}$ & $\begin{array}{l}17 \text { September } \\
2015\end{array}$ & 17 days \\
\hline 5. & $\begin{array}{l}\text { 08/Pdt . Sus - Pailit/2015/ } \\
\text { PN.Niaga. Sby }\end{array}$ & 02 July 2015 & $\begin{array}{l}16 \text { September } \\
2015\end{array}$ & 74 days \\
\hline 6. & $\begin{array}{l}\text { 02/Pdt . Sus - Pailit/2015/ } \\
\text { PN.Niaga. Sby }\end{array}$ & $\begin{array}{|ll|}20 & \text { Maret } \\
2015 & \end{array}$ & 27 Mei 2015 & 68 days \\
\hline
\end{tabular}

Source : Secondary data, 2017 
The deadline regulation for resolving petition for declaration of bankruptcy in the provisions of the UUK PKPU has resulted in the completion of bankruptcy applications within the stipulated period of the law. Application for settlement of petition for declaration of bankruptcy in a commercial court starts when the bankruptcy application is registered in the commercial civil registrar until it is decided by the judge must be completed within no more than 60 days under article 8 paragraph (4). Petition for declaration of bankruptcy must be completed quickly and effectively in the court so that it can restore the trust of foreign investors and restore the country's economy at that time (Muladi, 1998: 1. This quick settlement also conducted by carrying out simple burden of proof of debt for the Bankruptcy cases in the commercial court. The burden of proof of the debt case which categorized as not easy and simple, resulted in settlement of cases that take a long period is not the authority of the commercial court. The authority over such cases falls within the authority of the district court. In the decision to review the case of PT WRS Indonesia $v$ Rodney Alexander Bothwell [Decree of the Supreme Court of the Republic of Indonesia Number 02 PK/N/2001] The Supreme Court of the Republic of Indonesia ruled that the dispute that occurred in this case was regarding the event of default between the respondent (Pte Ltd. WRS Indonesia) as the employer and the applicant (Rodney Alexander Bothwell) as a worker. According to the Supreme Court of Indonesia, this matter should be examined and decided in advance according to the civil method in the district court, because the agreement was made based on a work agreement which verification was not simple and not easy. Rodney Alexander Bothwell should register the case to the district court and not the commercial court (See also the case of Pte Ltd. Kadi Internasional v. Pte Ltd. Wisma Calindra [Decree of the Supreme Court of the Republic of Indonesia Number 04.PK/N/2001] and Pte Ltd. Bank Mayapada International Tbk v. Pte Ltd. Mandira Pelita Utama [Decree of the Supreme Court of the Republic of Indonesia Number 33.PK/N/2001]).

The regulation concerning the deadline for the settlement of bankruptcy cases in the commercial court within a period of 60 days results in the dispute settlement becoming faster (Jameslin Purba, 2017: Interview; Agus Subroto, 2017: Interview) that is in accordance with the period regulation and the arrears of bankruptcy cases have been completed and there is no arrears of cases as happened in the district court by far, compared to the settlement in the previous district court. According to the Circular of the Supreme Court (SEMA) of Republic of Indonesia Number 6 of 1992, the settlement of civil cases (including herein the bankruptcy case at that time) in the district court was settled in a period of six months (180 days). This deadline regulation can be continued with the permission of the head of the district court (Agus Subroto, 2017: Interview).

528 Yustisia Vol. 7 Number 3 (Sept.-Dec. 2018) $\quad$ Deadline Settlement Of Petition ... 


\section{The legal consequences for judges who examine petition for declaration of bankruptcy if they do not heed the deadline regulation.}

Article 8 paragraph (5) of the $U U K$ PKPU states that the Court Decision on petition for declaration of bankruptcy must be resolved no later than 60 (sixty) days after the date the application registered. Based on this fact, the deadline regulation for settlement of petition for bdeclaration of bankruptcy no later than 60 days is imperative provisions (Dwingenregelen). The word "must" in the provisions of Article 8 paragraph (5) characterizes that this provisions are imperative/enforceable. However, if observed the provisions contained in $U U K P K P U$, there is no provision that regulates the legal consequences (sanctions) against judges who violate the provisions regarding the deadline for completing petition for declaration of bankruptcy.

Law as a system certainly relates to one legal system to another. Based on this fact, even though the $U U K P K P U$ does not regulate legal consequences for judges who violate the provisions of Article 8 paragraph (5) relating to the deadline for resolving petition for declaration of bankruptcy,however the judge is bound by supervision carried out by the Supreme Court in connection with this matter.

Based on Article 24 A paragraph (1) of the 1945 Constitution of the Republic of Indonesia states that

The Supreme Court shall have the authority to hear a trial at the highest (cassation) level, to review ordinances and regulations made under any law against such law, and shall possess other authorities as provided by law.

Based on the sentence " shall possess other authorities as provided by law". Other authorities referred to is the authority to oversee the court judge. The authority to oversee must be seen in the regulation of the Supreme Court. The oversight function of the Supreme Court (toeziende functie) is regulated in Law Number 48 of 2009 on Judicial Power (Judicial Power Law) and the Supreme Court Law. The purpose of supervision is to ensure judiciary is carried out carefully and appropriately with the reflection of the general principle of justice such as simple, fast and low cost (Article 2 paragraph (4) of the Judicial Power Law).

The object of supervision of the Supreme Court is (Henry P Panggabean, 2001: 136):

a. judicial technical issues concerning the administration or course of the trial;

b. actions and behavior of judges and court officials in carrying out their duties; and

c. administration of justice. 
Based on the provisions in Article 39 of the Judicial Power Law, it is stated that:

(1) Highest supervision towards the Organization of the judiciary in all judicial bodies that are under the Supreme Court's judicial power in performed by the Supreme Court.

(2) In addition to the supervision referred to in paragraph (1), the Supreme Court did the Supreme supervision towards the implementation of the administrative and financial tasks.

(3) The internal Supervision over the conduct of judges is done by the Supreme Court.

(4) Supervision and authority as referred to in paragraph (1), paragraph (2), and paragraph (3) shall not reduce the freedom of judges in examine and decide the case.

Article 32 of Law Number 3 of 2009 on the Second Amendment to Law Number

14 of 1985 on the Supreme Court (Supreme Court Law-P2) also mentions the supervisory function of the Supreme Court with the following formula:

a. The Supreme Court conducts the highest supervision of the administration of justice in all judicial bodies under it in carrying out judicial power;

b. In addition to this oversight, the Supreme Court conducts the highest oversight of the implementation of administrative and financial duties;

c. The Supreme Court has the authority to ask for information about matters pertaining to the judicial technicality of all judicial bodies that are under it;

d. The Supreme Court has the authority to give instructions, reprimand, or warnings to the courts in all judicial bodies below them;

e. The supervision should not reduce the freedom of the judge in examining and deciding cases.

The Supreme Court supervision policy as referred to in article 32 of Law Number 3 of 2009 is intended to realize the era of justice that is free of corruption, collusion and nepotism (Zainal Arifin Mochtar, 2016: 176).

Supervision of the Supreme Court relates to judicial technical issues concerning the administration or course of the trial of the judiciary (Henry P Panggabean, 2001: 136) as well as stipulated by article 39 paragraph (1) of the Judicial Power Law which states that the highest oversight of the administration of justice in all judicial bodies is under the Supreme Court in organizing judicial power carried out by the Supreme Court and article 32 number 1 of Law Number 3 of 2009 on the Second Amendment to Law No. 14 of 1985 on the Supreme Court ("Law 3/2009") which mentions the supervisory function by the Supreme

530 Yustisia Vol. 7 Number 3 (Sept.-Dec. 2018) $\quad$ Deadline Settlement Of Petition ... 
Court is to carry out the highest supervision of the administration of justice in all judicial bodies under it and carrying out judicial power

Based on the foregoing reasons, the legal consequences for judges violating the provisions of article 8 paragraph (5) of the $U U K$ PKPU by not resolving petition for declaration of bankruptcy vased on the deadline regulation stipulated by applicable law, even though the regulation does not provide sanctions/legal consequences for this matter, then of course the arrangements in other regulation demand for emphasized. Judges who do not comply with the technical issues of the judiciary concerning the administration or course of the trial such as violation of the provisions under article 8 paragraph (5) of $U U K$ PKPU by not resolving petition for declaration of bankruptcy based deadline regulation is the issue of the Supreme Court regarding the performance of the judge. In this case, the criminal sanction could not be charged, nevertheless the administrative sanctions relating to career and promotion of the judge could be charged. (Agus Subroto, 2017: Interview).

\section{E. CLOSING}

\section{Conclusion}

Based on the problems and results of the research and discussion as described in the previous ab, it can be concluded that:

a. Republic of Indonesia Law Number 37 of 2004 on Bankruptcy and Postponement of Obligation to Pay Debt (Bankruptcy Law and PKPU) regulates the time limit for resolving bankruptcy applications so that settlement of bankruptcy applications can be completed more quickly with the aim of restoring public confidence in court institutions. This is due to bankruptcy arrangements in previous legislative arrangements (Statute Book 1905 Number 217 jo Staatsbaat 1906 Number 348 on Vergeening Verification for Surgeance van Betaling (Faillissement Verordening) does not regulate the deadline for resolving bankruptcy applications.

b. Setting the deadline for resolving bankruptcy applications in the commercial court as stipulated in the Republic of Indonesia Law Number 37 of 2004 on Bankruptcy and Delaying Obligations of Debt Payments (Bankruptcy Law and $P K P U$ ) is carried out by the judge in examining and deciding bankruptcy applications. In 2015, the majority of bankruptcy applications in the commercial court $(87 \%)$ were completed within the deadline no more than what had been determined by the Republic of Indonesia Law Number 37 of 2004 on Bankruptcy and Delaying Obligations of Debt Payments (Bankruptcy Law and PKPU), and; 
c. Republic of Indonesia Law Number 37 of 2004 on Bankruptcy and Delay of Obligation to Pay Debt (Bankruptcy Law and PKPU) does not regulate sanctions for judges who violate the deadline for settlement of bankruptcy applications, however sanctions against violations do not comply with the time limit for bankruptcy applications in This court is regulated in other laws, namely in Law Number 48 of 2009 on Judicial Power (Judicial Power Law) and Supreme Court Law (MA Law). The Supreme Court has the authority to oversee the duties and performance of judges in the field of justice.

\section{Suggestion}

Based on the research conclusions described above, it is necessary to suggest:

a. The demand to maintain the deadline regulation for resolving petition for declaration of bankruptcy in the commercial court as stipulated in Law Number 37 of 2004 on Bankruptcy and Suspension of Debt Payment Obligation (Bankruptcy Law and $P K P U$ );

b. The demand for more supervision by the Supreme Court to ensure the deadline regulation for resolving this bankruptcy application is carried out by the judge in examining, adjudicating and deciding the petition for declaration of bankruptcy as for the settlement in the commercial court does not exceed the deadline specified in the Law Number 37 Year 2004 on Bankruptcy and Suspension of Debt Payment Obligation (Bankruptcy Law and PKPU); and;

c. The demand for the application of sanctions under other legislation for judges who violate the provisions of Article 8 paragraph (5) of the Republic of Indonesia Law Number 37 Year 2004 on Bankruptcy and Suspension of Debt Payment Obligation (Bankruptcy Law and PKPU).

\section{BIBLIOGRAPHY:}

\section{Books:}

Kumar, Ranjit, 1999, Research Methodology: a Step-by-Step Guide for Beginners. Addison Wedley Longman Australia Pty. Limited: Melbourne.

Mertokusumo, Sudikno 1998, Hukum Acara Perdata Indonesia (Indonesian Civil Procedural Law), Cetakan pertama, Edisi kelima, Liberty: Yogyakarta.

532 Yustisia Vol. 7 Number 3 (Sept.-Dec. 2018) $\quad$ Deadline Settlement Of Petition ... 


\section{Journals:}

Chowdhry, Bhagwam dan Amit Goyal, 2000, Understanding the Financial Crisis in Asia, Pasific-Basin Finance Journal 8, [http://www.elsevier.com/ locateleconbase] [20 April 2008].

Corsetti, Giancarlo Paolo Pesenti dan Nauriel Roubini, 1999, What Caused the Asian Currency and Financial Crisis?, Japan and the World Economy Journal 11, [http://www.elsevier.com/locate/econbase] [20 April 2008].

Johson, Simon Peter Boone, Alasdair Breach, Eric Friedman, Corporate Governance in The Asian Financial Crisis, 2000, Journal of Financial Economic 58: 171 http://www.elsevier.com/locate/econbase [20 April 2008].

Mitton, Todd 2002, A Cross-Firm Analysis of The Impact of Corporate Governance on The East Asian Financial Crisis, Journal of Financial Economic 64, [http://www.elsevier.com/locate/econbase] [20 April 2008].

\section{Newspaper:}

Budiyono, T, Sisi Hukum Pemailitan PT AJMI. Suara Merdeka. 3 Juli 2002 Himawan,

CH, Hukum Kepailitan Atau Kepailitan Hukum, Kompas, 19 Oktober 1998

Manning, C. 2000, Labour Market Adjustment to Indonesia's Economic Crisis: Price, Trends and Implications, Bulletin of Indonesian Economic.

\section{Interview:}

Purba, Jameslin 2017, Jangka Waktu Penyelesian Permohonan Pailit, Interview, Jakarta, 10 Agustus.

Purba, Jameslin 2017, Upaya Hukum Putusan Pailit, Interview, Jakarta, 10 Agustus.

Subroto, Agus 2017, Akibat Hukum Bagi Hakim terhadap Pelanggaran Pasal 8 ayat (5) ) Undang-Undang Kepailitan dan PKPU, Interview, Yogyakarta, 3 September.

Subroto, Agus 2017, Perbandingan Batas Waktu Penyelesaian Perkara di Pengadilan Niaga dan Pengadilan Negeri, Interview, Yogyakarta, 25 Juli.

Subroto, Agus 2017, Tujuan Diaturnya Batas Waktu Penyelesaian Permohonan Pailit, Interview, Yogyakarta, 25 Juli.

Subroto, Agus 2017. Batas Waktu Penyelesaian Perkara di Pengadilan Negeri, Interview, Yogyakarta, 25 Juli.. 